\title{
The Effect of Cover Crops and their Management on Plant-parasitic Nematodes in Vineyards
}

\author{
D.H.M. Kruger ${ }^{1}$, J.C. Fourie ${ }^{2}$, A.P. Malan ${ }^{1 *}$ \\ (1) Department of Conservation Ecology and Entomology, Stellenbosch University, Private Bag X1, Matieland 7602, South \\ Africa \\ (2) ARC Infruitec-Nietvoorbij, Private Bag X5026, Stellenbosch, 7599, South Africa
}

Submitted for publication: October 2014

Accepted for publication: January 2015

Key words: Biofumigation, cover crops, grapevine, integrated pest management, plant-parasitic nematodes

\begin{abstract}
In South Africa the use of annual cover crops is an established soil cultivation practice in vineyards that is environmentally friendly and financially sustainable in the long term. Species from the Brassicaceae family are well known for their biofumigation potential. In this study, Sinapis alba (white mustard), Brassica napus cv. AV Jade (canola), Brassica juncea cv. Caliente 199 (Caliente), Eruca sativa cv. Nemat and Avena sativa cv. Pallinup were established as cover crops in a vineyard for three growing seasons and evaluated for their biofumigation impact, as well as crop host impact on the suppression of economically important plant-parasitic nematodes. Mechanical and chemical cover crop management practices on Criconemoides xenoplax (ring nematode) and Meloidogyne javanica (root-knot nematode) numbers were determined. Canola and Caliente showed a consistent reduction of $C$. xenoplax present in the vine row 60 days after the management practices applied at the end of the third growing season. This trend was found during the three-year trial period for all different sampling periods $(0,15,30$ and 60 days). Lowered numbers for the total plant-parasitic nematodes were also found for the three-year trial period measured at 60 days after the management practice sampling period. The results can be attributed mainly to the crop host status of the two cover crop species towards $C$. xenoplax. White mustard showed a constant increase in $C$. xenoplax numbers in the vine row over the three-year period compared to the treatments in which no cover crop was sown.
\end{abstract}

\section{INTRODUCTION}

The phasing out of effective soil fumigation options, in addition to the pressure on other chemical control options, has caused the control of soil-borne pests to become an even greater challenge. The concept of biofumigation is not new and the first observations of this technique were already recorded at the beginning of the 17th century (Challenger, 1959). There are three areas in which biofumigation can have a positive effect in terms of integrated pest management (IPM), namely nematode control (Monfort et al., 2007), the control of soil-borne diseases (Lazzeri et al., 1993) and weed control (Brown \& Morra, 1997).

Certain crops, inter alia the brassica species, produce sulphur-containing secondary metabolites, with the main focus on isothiocyanate (ITC). Glucosinolates (GSL) present in the cells are hydrolysed by the enzyme myrosinase (MYR) to form the highly active ITC, which has a toxic effect on many soil-borne pathogens (Sarwar et al., 1998). There also are other secondary metabolites that form during the degradation of the crop tissues, including nitriles and thiocyanates (Fenwick et al., 1983). GSL can be grouped into three main groups, including aliphatic, aromatic and heterocyclic (Indole) (Fahey et al., 2001). The release of the active compound, ITC, takes place when the cell walls of these plants are ruptured (Matthiessen et al., 2004) and the GSL inside the vacuole of the cell comes into contact with the enzyme MYR, which is situated inside the cytoplasm of the cell (Poulton \& Moller, 1993).

To maximise the presence of the ITC in the soil during the biofumigation process, Brassica spp. with a high GSL concentration must be selected. Optimal cellular disruption should be achieved during the process of maceration and incorporation, whilst ensuring that sufficient soil moisture is present, both during and after incorporation (Poulton \& Moller, 1993; Morra \& Kirkegaard, 2002; Matthiessen et al., 2004). Water plays a role in the hydrolysis process, with GSL being hydrolysed to ITC, and it is essential that enough soil moisture is present in the soil for the desired reaction to take place (Lazzeri et al., 2004a; 2004b; Mathiessen et al., 2004).

Crop rotation is a principle that forms part of IPM and that is used successfully to suppress soil-borne diseases. Green manuring with selected Brassica spp. has rendered promising results in suppressing soil-borne pests and diseases (Larkin \& Griffin, 2007). Brassica napus (canola) residues suppressed 
certain wheat diseases, most probably because of the fungicidal compounds, like ITC, that are released during the breakdown process of the canola residues (Kirkegaard et al., 1996a,b; Sarwar et al., 1998). Canola and rapeseed (another Brassica napus cultivar) applied in a crop rotation system before the planting of Solanum tuberosum (potato) have also suppressed certain potato diseases, such as Rhizoctonia solani (Larkin \& Honeycutt, 2006). Different Brassica spp. have been evaluated for their capacity to suppress potato diseases, but Brassica juncea (Indian mustard) has been found to be the most effective in inhibiting fungal growth in in vitro tests (Larkin \& Griffin, 2007). In grape production, cover crops established in the inter-row reduced water runoff and erosion (Louw \& Bennie, 1992), restricted evaporation from the soil surface (Van Huyssteen et al., 1984; Myburgh, 1998), conserved soil water (Buckerfield \& Webster, 1996) and also reduced temperature fluctuations in the soil (Fourie \& Freitag, 2010). It also facilitated the effective suppression of both winter- and summer-growing weeds (Fourie et al., 2005, 2006; Fourie, 2010). Cover crops in vineyards have also been studied for their effect on plant-parasitic nematodes (Addison \& Fourie, 2008). It has been observed that certain grass species, as well as certain broad-leaf species, have the potential to suppress plant-parasitic nematodes. The ability of certain Brassica spp. to suppress nematode pests is well documented (Mojtahedi et al., 1991; 1993; McLeod \& Steel, 1999; Melakeberhan et al., 2006). Brassica cover crops in vineyards are known for their biofumigation potential and showed promising results as part of an integrated approach for Meloidogyne javanica (Treub, 1885; Chitwood, 1949) suppression. Indian mustard cv. Nemfix grown in the grapevine inter-row and applied as a green manure, either to the vine row or inter-row, suppressed $M$. javanica numbers (Rahman \& Somers, 2005).

Worldwide, the most important plant-parasitic nematodes associated with grapevines are $M$. javanica spp. (root-knot nematode), Pratylencus spp. (root lesion nematode), Criconemoides xenoplax (Raski, 1952) Loof and De Grisse, 1976 (ring nematode) and Xiphinema spp. (dagger nematode) (McKenry, 1992; Pinkerton et al., 1999; Walker \& Stirling, 2008). In Australia, plant-parasitic nematodes are problematic in all the different grape-growing regions (Nicol et al., 1999), and in South Africa grapevines are also host to a wide range of pest nematodes (Smith, 1977; Loubser \& Meyer, 1987a; 1987b).

The economic impact of plant-parasitic nematodes on a variety of crops is estimated to range between 5 and $15 \%$ and in some cases may be the main limitation factor in the production of specific crops (Stirling, 2014). The impact of nematodes on grapevines is less obvious and normally manifests when the grapevines are under some sort of stress, such as water stress (Ferris \& McKenry, 1975). Symptoms of vines infected with Meloidogyne spp. include poor vigour, stunted growth and poor yields (Seinhorst \& Sauer, 1956). It is very important to note, however, that Xiphinema index (Thorne \& Allen, 1950), which is present in high numbers in some viticulture regions in South Africa, not only damages the roots of susceptible grapevine cultivars, but also is a vector for the grapevine fanleaf virus (Malan \& Meyer, 1992, 1994, 1999).
The management of plant-parasitic nematodes in viticulture in South Africa currently is based on chemicals, registered under the Fertilisers, Farm Feeds, Agricultural Remedies and Stock Remedies Act, No 36 of 1947. The following active ingredients are registered: cadusafos, fenamifos and furfural (Hugo et al., 2014). The use of resistant rootstocks also forms part of an integrated approach to nematode management in South African vineyards. The rootstocks available are classified as resistant, moderately resistant, moderately susceptible and susceptible, with most of the rootstocks available having genetic resistance to rootknot nematodes (Loubser \& Meyer, 1987b). No rootstocks currently are available that are resistant to C. xenoplax (Storey, 2012).

The main objective of this study was to obtain scientifically based guidelines for the sustainable use of cover crops in vineyards as part of a nematode management programme. Firstly, cover crops were selected for their potential to biofumigate the soil as a means of suppressing plant-parasitic nematodes in vineyards. Secondly, the two management practices (green manuring versus no till at grapevine bud break) could indicate the role that green manure itself can play in the suppression of plant-parasitic nematodes (cover crops with no or little biofumigation properties), as well as the effect that the cover crop host status has on the long-term suppression of plant-parasitic nematodes.

\section{MATERIALS AND METHODS \\ Experimental vineyard and layout}

The three-year study (2009/2010, 2010/2011 and 2011/2012 seasons) was executed in a seven-year-old Shiraz/101-14 drip-irrigated vineyard, established on a sandy to sandy clay loam soil (Fourie et al., 2015) near Stellenbosch in the Western Cape, South Africa. The rootstock is classified as being mildly resistant to root-knot nematodes (Loubser \& Meyer, 1987b). Stellenbosch receives approximately $673 \mathrm{~mm}$ of rain annually, of which approximately $73 \%$ falls from March to August. Before the start of the field trial, nematode soil samples were collected on a random basis to determine whether the site was suitable as a nematode trial site. Grapevine cultivation practices conducted on this site were in keeping with the standard practices applied in vineyards in South Africa. The vineyard was drip irrigated from December to March. Seedbed preparation for the cover crops and the amount of fertilisers applied are described in Fourie et al. (2015).

Fourteen treatments were applied, consisting of five cover crop species, namely Avena sativa cv. Pallinup (Pallinup oats), Sinapis alba cv. Braco (white mustard), Brassica napus cv. AV Jade (canola), Brassica juncea cv. Caliente 199 (Caliente) and Eruca sativa cv. Nemat (Nemat). The cover crops were managed according to two management practices (10 treatments). These treatments were compared to two treatments in which no cover crop was sown and the weeds were managed according to the above-mentioned two management practices. Another two similar treatments were applied, in which a nematicide (Rugby 10ME, active ingredient cadusafos) was applied to the vine row at $15 \mathrm{~mL} / \mathrm{m}^{2}$. The management practices applied 
consisted of (1) full-surface chemical control of cover crops/ weeds from just before bud break to grapevine harvest (CC) and (2) chemical control in the vine row and mechanical incorporation of the weeds/cover crops in the work row just before bud break, followed by CC from berry set (MC). The treatments were replicated five times in a randomised block design. Each plot (replication) consisted of a surface area of approximately $83 \mathrm{~m}^{2}$. A vine row functioned as a buffer zone between treatments situated in different work rows, and a buffer area the length of five vines was left between the experimental vines of treatment plots situated in the same vine row.

The cover crops were mechanically and chemically controlled between late bloom and early seed/pod formation, which coincided with grapevine bud break. This resulted in the management practice being applied on 25 August, 3 September and 10 September during the 2009/2010, 2010/2011 and 2011/2012 grape growing seasons respectively. The mechanical maceration of green material was done by means of a standard weed slasher and the macerated material was incorporated into the soil with a disc harrow to a depth of $200 \mathrm{~mm}$. The incorporation was timed to coincide with a high soil water content, as water plays an important role (hydrolysis) during biofumigation (Matthiessen et al., 2004). According to Lazzeri (L. Lazzeri, personal communication, 2012), if the soil moisture level is $66 \%$ of field water capacity by the time of incorporation, irrigation or rainfall after incorporation is not essential and biofumigation can be expected to take place. Post-emergence weed control during grapevine bud break was achieved with glyphosate in both the $\mathrm{CC}$ (work row and vine row) and MC treatments (vine row), as described by Fourie et al. (2015). The standard pest and disease management programme used by the farm was applied.

\section{Extraction and identification of nematodes}

To determine the effect of the selected cover crops and cover crop management practices on the nematode numbers, a composite soil sample was taken from the 0 to $250 \mathrm{~mm}$ soil layer of each plot at the beginning of April (before the reestablishment of the cover crops), as well as on day 0 (just before the management practices were applied), and day 15 , day 30 and day 60 after the application of the management practices. The samples were taken in the work row or interrow, as well as in the vine row and were analysed separately. Each sample consisted of five subsamples taken diagonally across the work row, as well as underneath the vines in the vine row. Nematodes were extracted from the soil using a sugar centrifugation technique, based on the method used by Kleynhans et al. (1996).

Soil samples were mixed in the laboratory and the nematodes were extracted from a $250 \mathrm{ml}$ subsample using a sugar flotation technique (Jenkins, 1964). The nematodes were then counted and identified using a light microscope according to the technique described by Kleynhans et al. (1996).

\section{Statistical analysis}

The different cover crop treatments were applied for three consecutive seasons in 2009/2010, 2010/2011 and
2011/2012. Ten experimental grapevines per plot were used for measurements. An analysis of variance was performed separately for each season using the Statistical Analysis System (SAS, 1990). Student's $t$ least significant difference (LSD) was calculated at the 5\% and 10\% significance levels to facilitate comparison between treatment means. The Shapiro-Wilk test was performed to test for non-normality (Shapiro \& Wilk, 1965).

\section{RESULTS AND DISCUSSION}

The plant-parasitic nematode species identified in the soil samples over the three seasons were $M$. javanica, C. xenoplax and Xiphinema spp. Criconemoides xenoplax and $M$. javanica occurred in the greatest number in all soil extractions. The extraction of Pratylenchus spp. from the roots was done in the first year, but it was discontinued because of low nematode numbers.

\section{Effect of cover crops, without management practices, on $C$. xenoplax numbers in the vine and work row}

All the cover crop treatments, with the exception of Pallinup oats and white mustard in 2010, showed a constant, yearby-year increase in dry matter production (DMP) from 2009 to 2011 (Fourie et al., 2014). This is an important trend, as it can be expected that, with a higher DMP, the potential of the biofumigation cover crops to actively perform the biofumigation action after maceration and incorporation is enhanced (Morra \& Kirkegaard, 2002; Matthiessen et al., 2004). The importance of DMP is also stressed in work done by Rahman and Somers (2005), who found that the suppression of M.javanica in vineyards was better with higher biomass being applied to the infested soil. Stirling and Potter (1998) also found that at least $2 \mathrm{t} / \mathrm{ha}$ of Brassica biomass are needed for a significant biocidal impact, while Stirling and Stirling (2003) indicated a reduction of $M$. javanica after the application of 17 ton DMP/ha in comparison to the impact of lower DMP, but could not determine whether the reduction was specifically due to the ITC release or perhaps due to other, secondary aspects. The DMP of Nemat (MC) was below 2 tons/ha for all three seasons (Fourie et al., 2015) and, bearing in mind the work by Stirling and Potter (1998), this treatment is not expected to have a dramatic impact on the $M$.javanica numbers, as the amount of biomass produced and therefore the potential to form ITC was very low.

The interaction year, time, position and practice in the vine row was found not to be significantly different $(\mathrm{p}=0.86)$. The least significant difference (LSD) on a $95 \%$ confidence interval was found to be 208.26. Fluctuations in population levels of $C$. xenoplax occurred in the vine row from day 0 to day 60 within each year and fluctuation also was evident between the different years and cover crops (Fig. 1). Two important periods to consider are day 0 to day 60 for a specific year and day 60 to day 0 between seasons. These periods indicate the impact of the cover crops on C. xenoplax after the management practice has been carried out (day 0 to day 60 ), and also the impact of the cover crops on C. xenoplax numbers during active growth (day 60 to day 0 of the following season).

White mustard, Nemat and the treatment in which no 
Oats

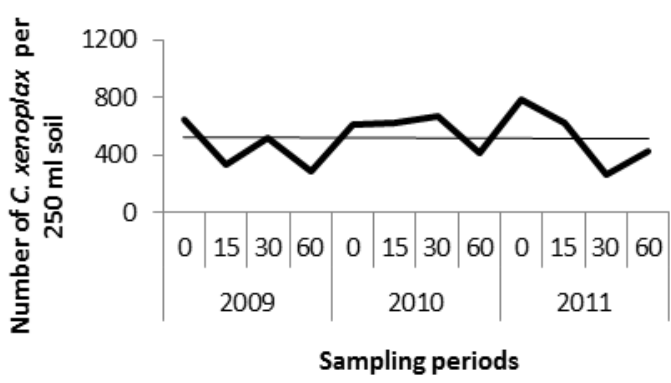

Canola

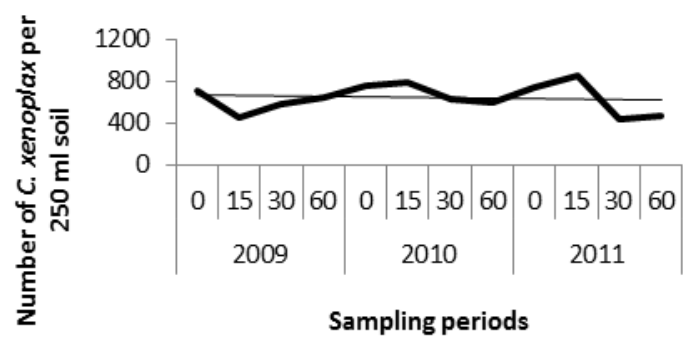

Nemat

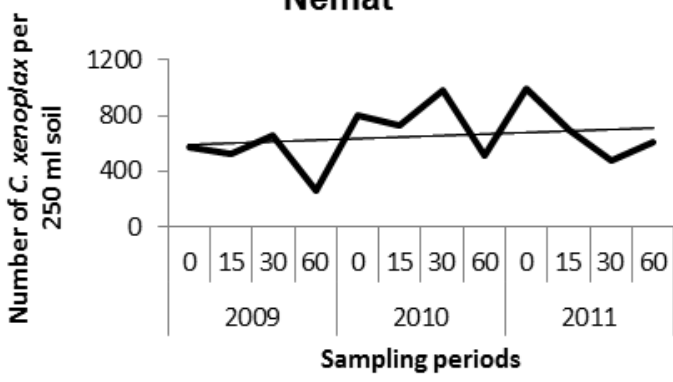

White mustard

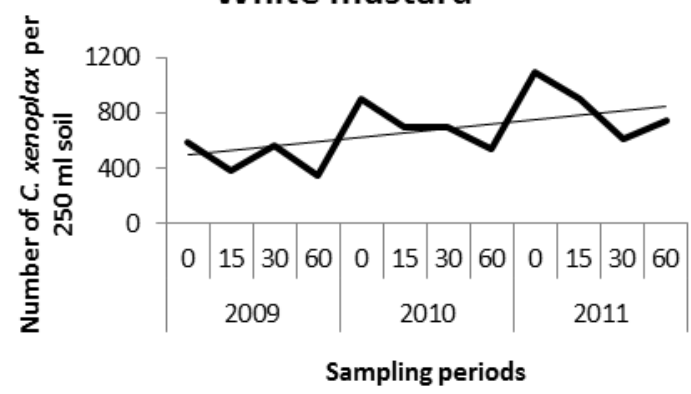

Caliente 199

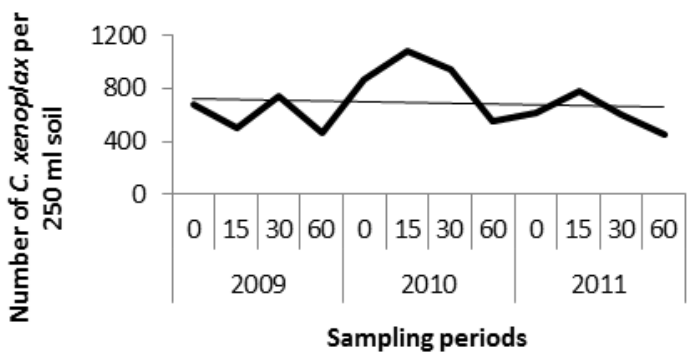

Weeds

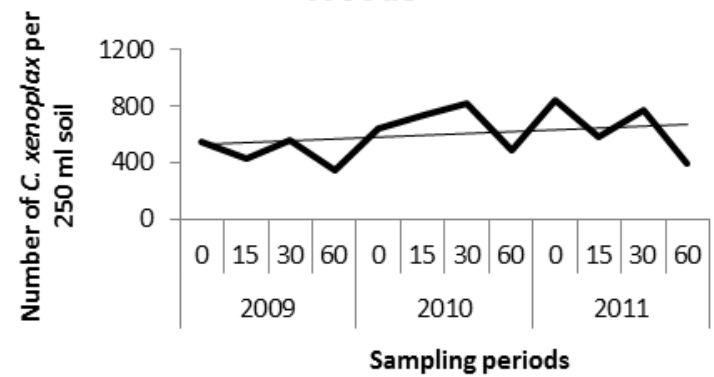

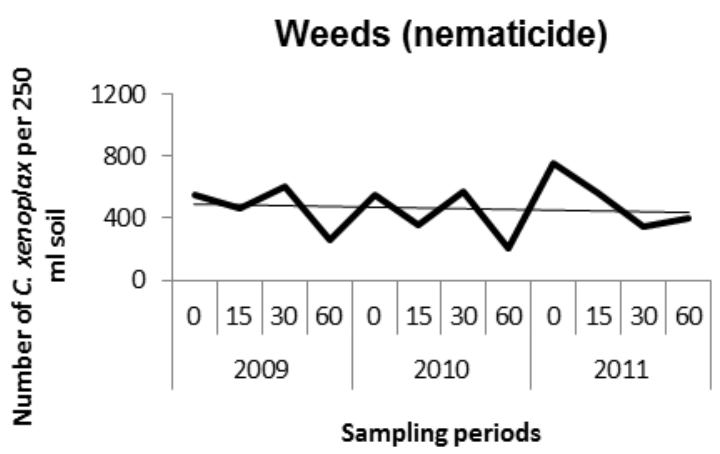

FIGURE 1

Fluctuations in population levels of Criconemoides xenoplax for three years (2009, 2010 and 2011) when considering the effect of the cover crop alone.

cover crop was sown and a nematicide was applied (Weeds nematicide) showed a significant decrease in C. xenoplax (day 0 to day 60) in the vine row for the three years when looked at separately (Fig. 1). This seems to be a positive result, but when the total impact from 2009 (day 0) to 2011 (day 60) is considered, white mustard and Nemat were the only two crops indicating an increase in C. xenoplax. Weeds (nematicide) did not show the same increase over the total period. White mustard and Nemat showed a similar long- term trend in relation to the treatment in which no cover crops were sown and in which no nematicide was applied (Weeds). An important reason for this is the fact that there was a significant increase for these two treatments from in day 60 to day 0 period for both 2009/2010 and 2010/2011. All the other crops, except canola (2009/2010 and 2010/2011) and Caliente 199 (2010/2011) showed a significant increase in C. xenoplax from day 60 to day 0 for the 2009/2010 and 2010/2011 periods. The increase that took place for 
white mustard and Nemat during this period was the most prominent and was significantly higher than canola during both seasons. The $C$. xenoplax numbers in these two crops were higher at the beginning of the grapevine growing season because of the strong build-up over the period from day 60 to day 0 , which resulted in the higher $C$. xenoplax levels over time. The increase in C. xenoplax for canola (2009/2010 and 2010/2011) and Caliente 199 (2010/2011) in the period from day 60 to day 0 was not significant. It also was these two crops that showed a constant decreasing trend that compared well with Weeds (nematicide) over the total period (2009 to 2011). A possible explanation for the above finding is shown in a C. xenoplax crop host trial in which canola and Caliente 199 showed the lowest $C$. xenoplax numbers in comparison with the other crops tested (Kruger et al., 2015).

\section{Work row}

The amount of C.xenoplax in the work row was significantly lower in all cases than the numbers in the vine row for the specific year, crop and time. Very little C. xenoplax was present in the work row and no specific conclusion or trend with regard to the impact of the cover crops on the C. xenoplax could be made (data not shown). What is clear is that there was an increase in C. xenoplax in 2011, with constantly more nematodes present at the specific sampling times (day 0 , day 15 , day 30 and day 60). However, the trend is not restricted to a specific crop and the same trend occurs in Weeds (control). This could be ascribed to the total crop biomass produced being higher in 2011 than in 2009 and 2010 (Fourie et al., 2015). With an increase in biomass, root biomass will also increase and provide the potential for better nematode establishment.

Effect of cover crops, without management practices, on M. javanica numbers in the vine and work row

The $M$. javanica numbers in the vine and work row were low throughout the study, with lower $M$. javanica numbers present in the work row compared to the vine row (data not shown). However, these numbers are not expected to pose an economic threat to the growth and yield of the vineyards (S.G. Storey, personnel communication, 2013). The same trend as was the case for the C.xenoplax was observed for the day 60 to day 0 period, with both 2009/2010 and 2010/2011 showing significant increases in $M$. javanica (data not shown). This trend was attributed to the climatic conditions being favourable for the numbers to build up over these periods (Fourie et al., 2015). Except for Weeds (nematicide) (Fig. 2), no economically important $M$. javanica increase was observed for these crops over time, which is regarded as a very positive result.

The overall effect of the cover crops and management practices on $C$. xenoplax numbers in the vine and work row

The interaction between year, time, position and crop/ practice $(\mathrm{CP})$ was taken into consideration for the three growing seasons. Significant differences were observed in C. xenoplax numbers measured in the vine row, between the different sampling times within a specific treatment and between the different treatments (Table 1). Comparing day 0 (end of August) and day 60 (end of October/beginning of November) for each treatment from 2009 to 2011, white mustard (MC), canola (MC), and Weeds (nematicide) (CC) showed a similar trend, with a significant decrease in C. xenoplax between day 0 and day 60 . All treatments except canola (CC) showed a similar, although not significant, trend. However, in most cases this was not a constant decrease over the total period (day 0 , day 15 , day 30 and day 60), with fluctuations in the nematode numbers on day 15 and day 30 . A natural decrease in C. xenoplax numbers can be expected to occur at the end of October/beginning of November (day 60 ), as the soil moisture content in the top $25 \mathrm{~cm}$ of soil decreases, with not much rain falling between the end of September and early November (Table 2) and with irrigation starting only in December, bearing in mind that nematodes move with water. Canola (CC) showed a significant increase

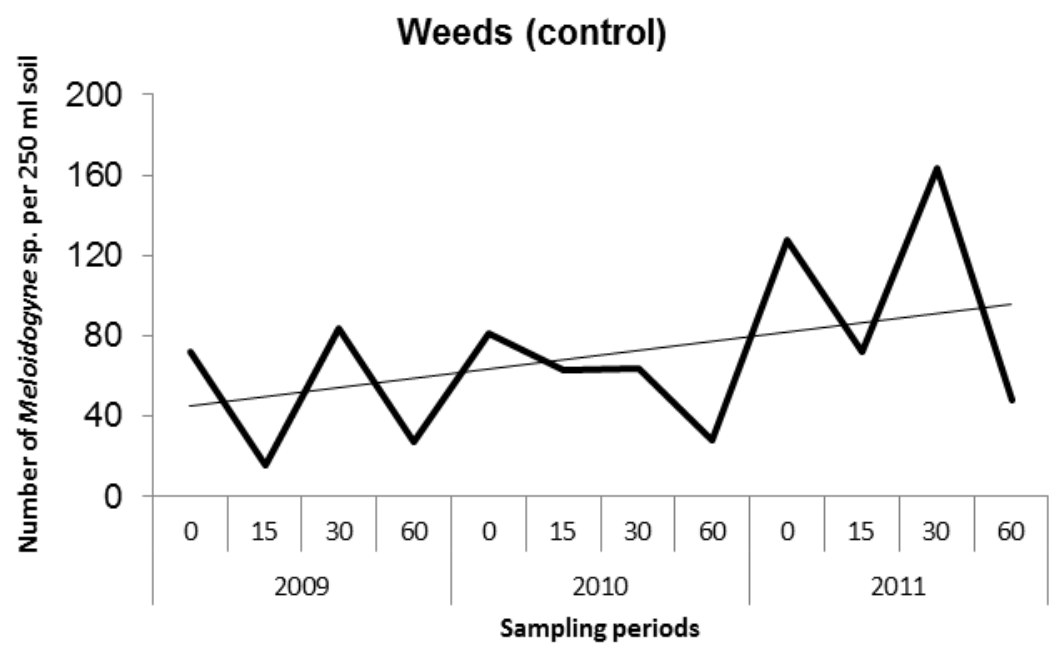

FIGURE 2

The effect of the treatments in which no cover crop was sown (Weeds) on the Meloidogyne javanica numbers in the vine row for the period 2009 to 2011 . 


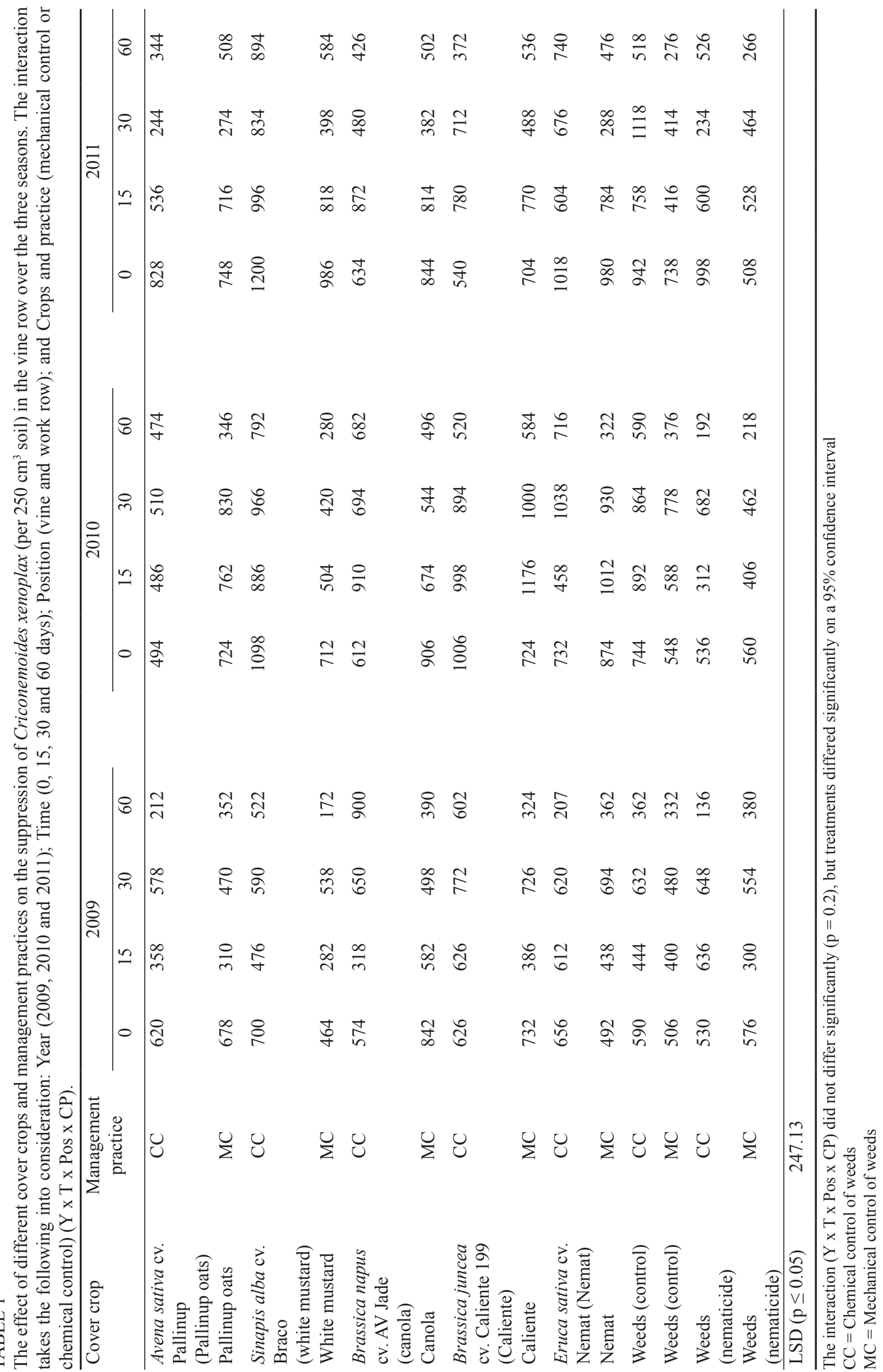


in C. xenoplax between day 0 and day 60 in 2009, with no statistical decrease observed in 2010 and 2011 (Table 1).

Another factor involved is the period from day 60 (end of October/beginning of November) to day 0 (August). This period includes the very warm months of December, January, February and March, and on this specific trial site irrigation was given during this period by means of drip irrigation. All these factors (temperature, water and a favourable host) allow C. xenoplax numbers to build up. In most treatments a significant increase in the C.xenoplax numbers, or at least an

\section{TABLE 2}

Weekly summer rainfall $(\mathrm{mm})$ for the period September to November over three seasons as measured at Alto weather station, close to the trial site.

\begin{tabular}{llll}
\hline Period & 2009 & 2010 & 2011 \\
\hline 1 September - 7 September & 36 & 12 & 22 \\
8 September - 14 September & 28 & 3 & 9 \\
15 September - 21 September & 11 & 15 & 16 \\
22 September - 28 September & 28 & 12 & 0 \\
29 September - 5 October & 1 & 0 & 2 \\
6 October - 12 October & 49 & 25 & 0 \\
13 October - 19 October & 6 & 2 & 28 \\
20 October - 26 October & 9 & 9 & 0 \\
27 October - 2 November & 3 & 0 & 6 \\
3 November - 9 November & 85 & 24 & 7 \\
10 November - 16 November & 25 & 9 & 29 \\
17 November - 23 November & 0 & 21 & 24 \\
24 November - 30 November & 0 & 2 & 0 \\
\hline
\end{tabular}

increasing trend, was observed from day 60 in 2009 to day 0 and day 60 in 2010, up to day 0 in 2011 (Table 1). Once again it was only canola (CC) that showed a decline compared to the rest of the treatments, with a significant decline in the C. xenoplax numbers from day 60 in 2009 to day 0 in 2010 , followed by a declining trend from day 60 in 2010 to day 0 in 2011. Because of the variances that occurred between the two different periods, namely from August to the end of October/ beginning of November and from the end of October/ beginning of November to August, the effects over the threeyear period at day 0 (just before the management practice) and day 60 (after the management practice) are considered to give the best indication of the impact of the crop host and the long-term impact of the treatments respectively. In the day 0 analysis for the three years there was no significant decrease in any of the treatments. White mustard (CC and $\mathrm{MC})$, Nemat (CC and MC), Weeds (CC) and Weeds (nematicide) (CC) had significantly higher $C$. xenoplax numbers in 2011 than in 2009. This may be an indication that white mustard and Nemat may be good hosts for C. xenoplax and therefore can contribute to a build-up in numbers during the cover cropgrowing season (April to August). The other treatments, except for Caliente (CC), also showed an increasing trend from 2009 to 2011, albeit not significant.

At day 60 from 2009 to 2011, the canola (CC) treatment showed a decreasing trend in $C$. xenoplax in the vine row (Fig. 3). This is the only treatment for which there was a significant difference in the $C$. xenoplax numbers between 2009 and 2010 and also between 2009 and 2011.

Caliente, Weeds (MC) and Weeds (nematicide) (MC) showed a similar trend, although not significant. A similar trend was also observed for canola (CC) and Caliente when the effect on the total plant-parasitic nematode numbers, as measured at day 60 over three seasons, was considered (Fig. 4). When the C. xenoplax numbers of the canola (CC) treatment were compared with the Weeds (CC and

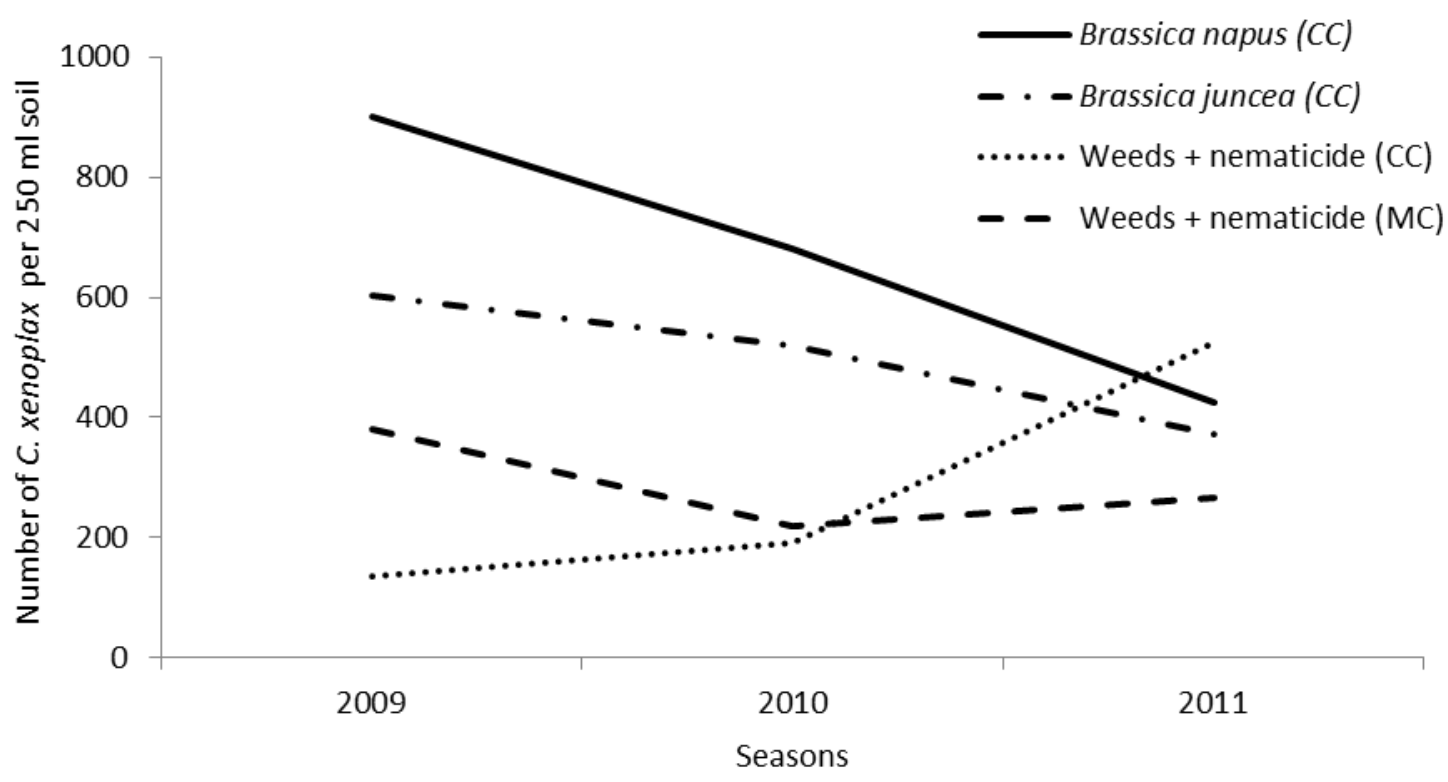

FIGURE 3

Criconemoides xenoplax numbers in the vine row, measured 60 days after the application of the management practices in the 2009, 2010 and 2011 seasons. 
$\mathrm{MC})$, as well as with the Weeds (nematicide) (CC and MC) treatments, the starting numbers in 2009 (day 60) were significantly higher, with a decreasing trend manifesting to such an extent that there was no significant difference between these treatments measured in 2011 (day 60). On the other hand, the numbers of $C$. xenoplax in the vine row for the white mustard (CC and MC), Nemat (CC), Weeds and Weeds (nematicide) (CC) treatments were significantly higher in 2011 than in 2009. Pallinup oats (CC and MC), canola (MC), Caliente (MC), Nemat (MC) and Weeds (CC) all showed similar increasing trends from 2009 (day 60 ) to
2011 (day 60).

Although it is impossible to eradicate plant-parasitic nematodes from the soil, the aim remains to suppress numbers to below the economic threshold level for the crop involved. In work done by McKenry (1992) it was found that economic damage in the sense of yield reduction was prevalent in Californian vineyards in which C. xenoplax was present in numbers of more than $500 / \mathrm{kg}$ soil. Therefore, nematodes should be managed continuously to prevent an increase in numbers to the point where it can have a negative economic impact.

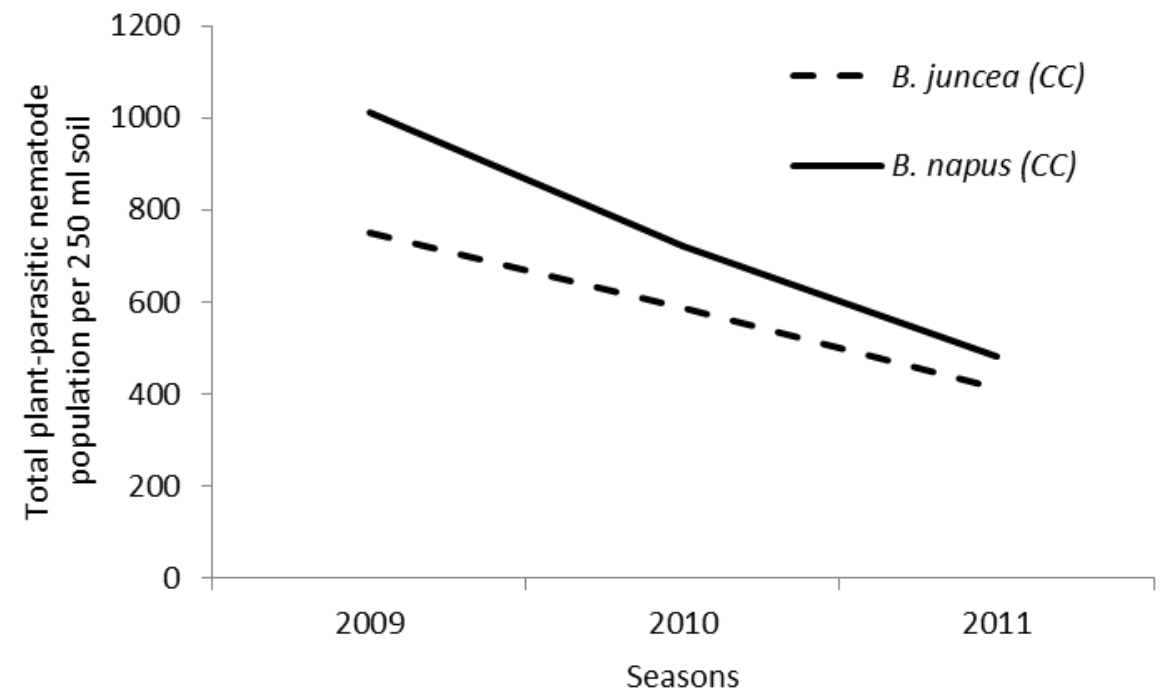

FIGURE 4

Total plant-parasitic nematode numbers determined in the vine row, 60 days after the management practices were applied.

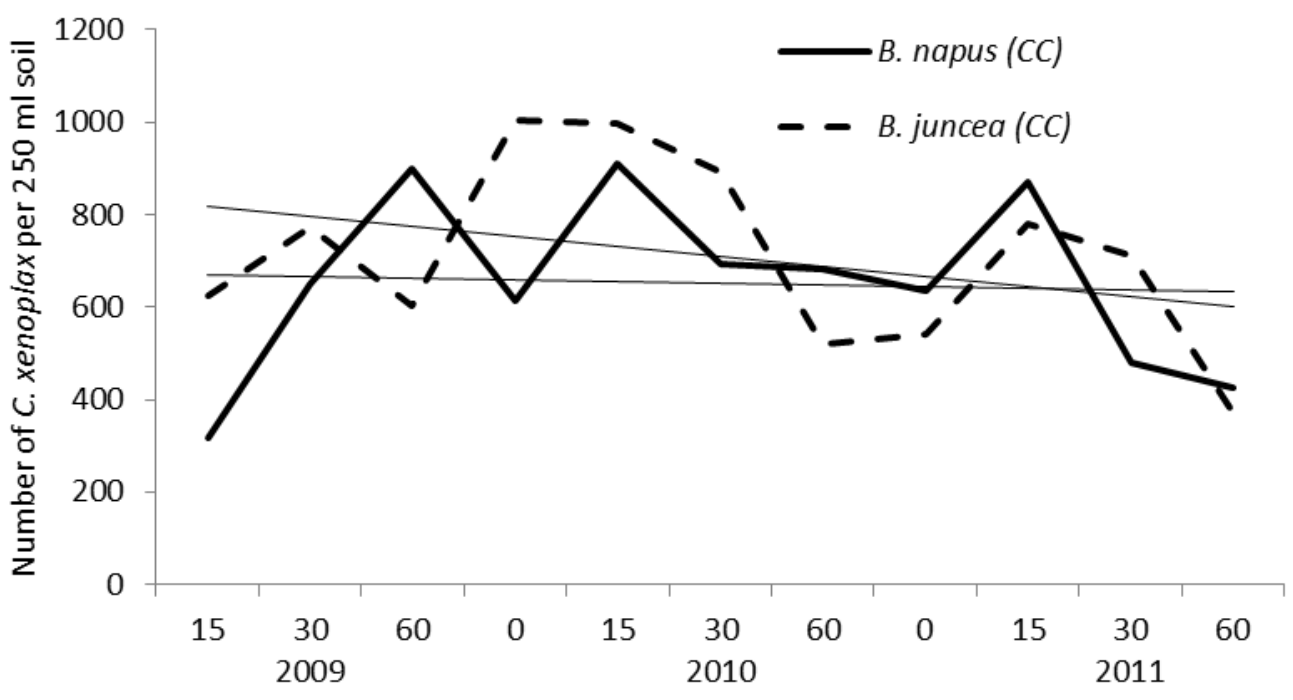

Sampling periods

FIGURE 5

The effect of Brassica juncea cv. Caliente 199 (Caliente) controlled chemically (CC) from bud break and Brassica napus cv. AV Jade (canola) (CC) on the suppression of Criconemoides xenoplax in the vine row at different sampling periods (day 0 , day 15, day 30 and day 60) during 2009, 2010 and 2011. 
The overall trend of Canola (CC) and Caliente (CC) on C. xenoplax at all sampling dates over the three growing seasons is shown in Fig. 5. There were fluctuations in the C. xenoplax numbers in each season, as well as between the seasons and sampling periods. However, a long-term decreasing trend was established. Nemat (MC), Weeds (CC) and Weeds (nematicide) (MC) showed a similar long-term trend, although not as prominent. The results obtained cannot be ascribed to the biofumigation effect on C. xenoplax, because the biomass had not been macerated and incorporated into the soil at that time. Thus the effect of concern here should rather be attributed to the crop host status that suppressed the development of the C. xenoplax in the vine row.

There was significantly less $C$. xenoplax present in the work row area compared to the vine row area (Tables 1 and 3). This was the case for all the treatments measured at day 0 and at day 15 in all three seasons. Factors that can play a role in this trend are soil moisture, the host status of the crops present in the work row and the grapevine host status in the vine row, while the irrigation in the vine row could also contribute. The differences between the $C$. xenoplax numbers in the work row compared to the $C$. xenoplax numbers in the vine row were less prominent in 2011 (day 30 and day 60), with Pallinup oats (CC), white mustard (MC), Nemat (MC), Weeds (MC) and Weeds (nematicide) (CC) not differing significantly at day 30, and Caliente 199 (CC), Weeds (MC) and Weeds (nematicide) (MC) also not differing significantly 60 days after the management practice was applied. It is also important to note that the DMP of the cover crops was higher in 2011 than in 2009 and 2010, with the exception of white mustard (CC) in 2010 (Fourie et al., 2015). This might have had a dramatic impact, from a root and shoot biomass perspective, on the potential role that these cover crops could play in nematode suppression. Except for white mustard (CC) at day 30 in 2011, which differed significantly from some of the other periods, there was no significant difference between the $C$. xenoplax numbers present at the different time periods for the different treatments.

\section{The overall effect of the cover crops and management practices on $M$. javanica numbers in the vine and work row}

The overall presence of $M$. javanica in this trial site was lower than the C. xenoplax numbers (Tables 1, 3, 4 and 5). The number of the $M$. javanica in the vine row (Table 4) also was higher than that observed in the work row (Table 5). Overall there were no significant differences in the numbers of $M$. javanica recorded in the work row between treatments, with the exception of white mustard (CC) at day 15 in 2010 (15 days after the management practice), which was significantly higher than most of the other work row numbers over all the time periods. Once again the two periods were considered, namely day 0 to day 60 (August to end of October/beginning of November) and day 60 to day 0 (end of October/beginning of November to August), which indicate the period after the management practices were applied to the cover crops and the period during which the cover crops were growing actively respectively.

In the vine row, the period from day 0 to day 60 for
2009, 2010 and 2011 indicated a decreasing trend every year, as also was the case for all the treatments and year intervals, except for Nemat in 2009 (Table 4). This indicated, as in the case of $C$. xenoplax, that a normal decrease in the nematode numbers could be expected over this period. For the period from day 60 to day 0 there was a significant increase in numbers in the vine row for the Weeds (MC) treatment in 2009/2010 and 2010/2011, with a significant increase also occurring for oats (MC), white mustard (CC and $\mathrm{MC}$ ), Nemat (CC and MC), Weeds (CC) and Weeds (nematicide) (CC and MC) in 2010/2011. The observed significant increases in the numbers of $M$. javanica were ascribed to the increases in biomass production of the above-mentioned cover crops from the 2009/2010 season to the 2010/2011 season. In the case of Nemat this does not support the results from a glasshouse trial in which the nematode host status of the cover crops species was determined. Kruger et al. (2015) found Nemat to be a poor host for M. javanica in glasshouse trials.

There were no significant increase in the $M$. javanica in the work row, comparing the starting numbers at day 0 (2009) with the end numbers day 60 (2011) (Table 5). No significant difference was found between the different cover crops with regard to the suppression of $M$. javanica, measured at the 60 day sampling period for 2009, 2010 and 2011. Even though this data does not show any clear reaction on the $M$. javanica in a specific time period or over the whole time spectrum, the fact that there was no significant increase, when the total period was considered, is an indication that these cover crops do not increase the numbers to such an extent that it may have an economic impact.

\section{Effect of the management practice on $C$. xenoplax numbers in the vine and work rows}

The $C$. xenoplax numbers in the vine row of the CC management practice were always higher than those of the vine row in the treatments to which MC was applied (Fig. 6). The differences within the periods, however, were not always significant and it was only at day 30 and day 60 that significant differences were found between $C$. xenoplax numbers and the management practices. A possible explanation for this trend is the impact of the incorporation of green manure into the soil, which results in biodiversity in the soil that indirectly influences the $C$. xenoplax numbers in the vine row. The more acceptable reason is most probably the effect that physical mechanical impact has on nematode numbers. A positive result was indicated in the comparison between day 0 (CC and MC) and day 60 (CC and MC); in both cases there was a significant decline in $C$. xenoplax. These results indicate that it was not the management practice alone that affected the nematode numbers. There were significant differences between the vine row numbers and the work row numbers of $C$. xenoplax in all periods. The work row numbers did not differ significantly over the three years and between the sampling periods for the different management practices, as shown in Figure 6.

Effect of management practice on $M$. javanica numbers in the vine and work row

The impact of the management practice on the $M$. javanica 


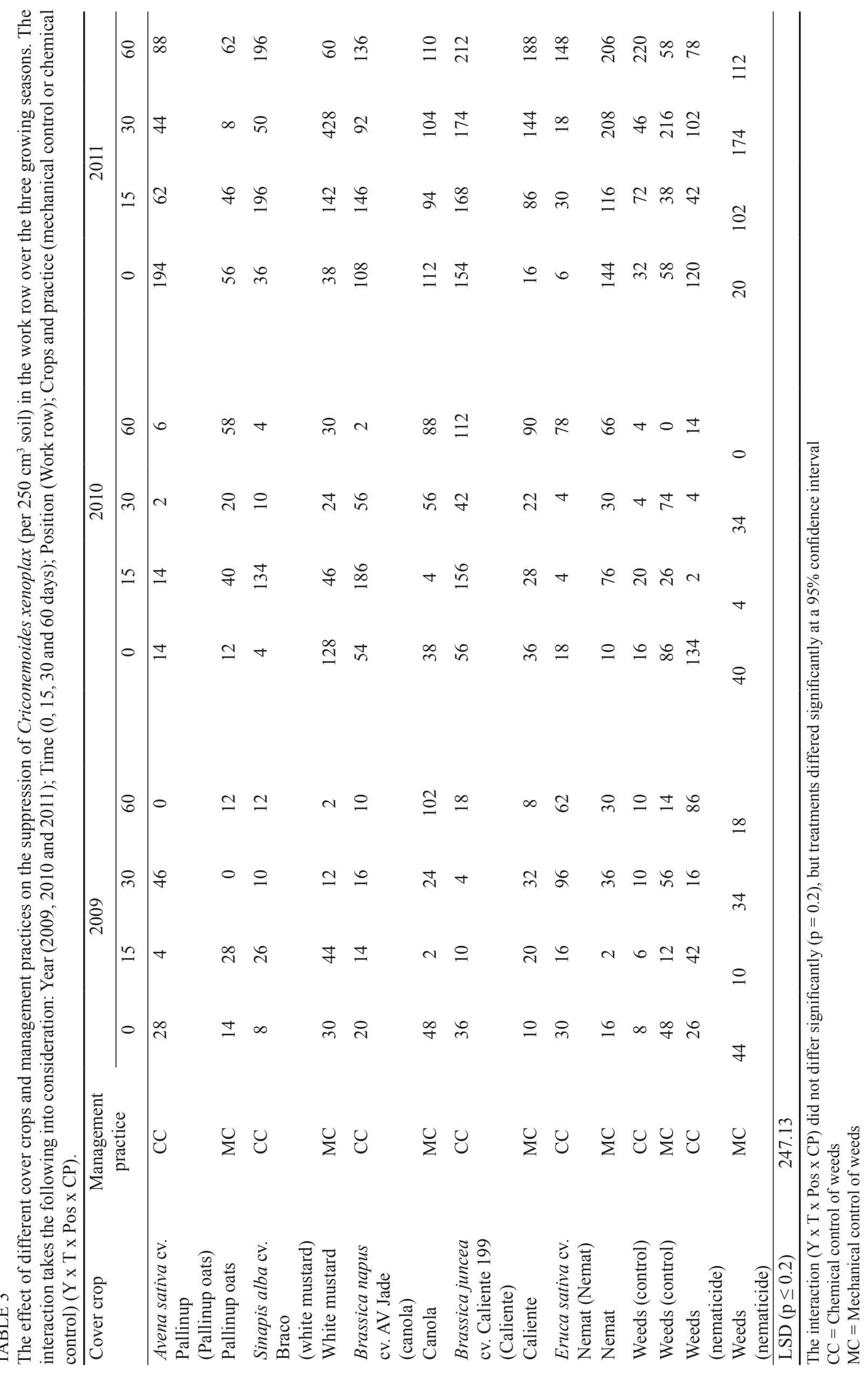




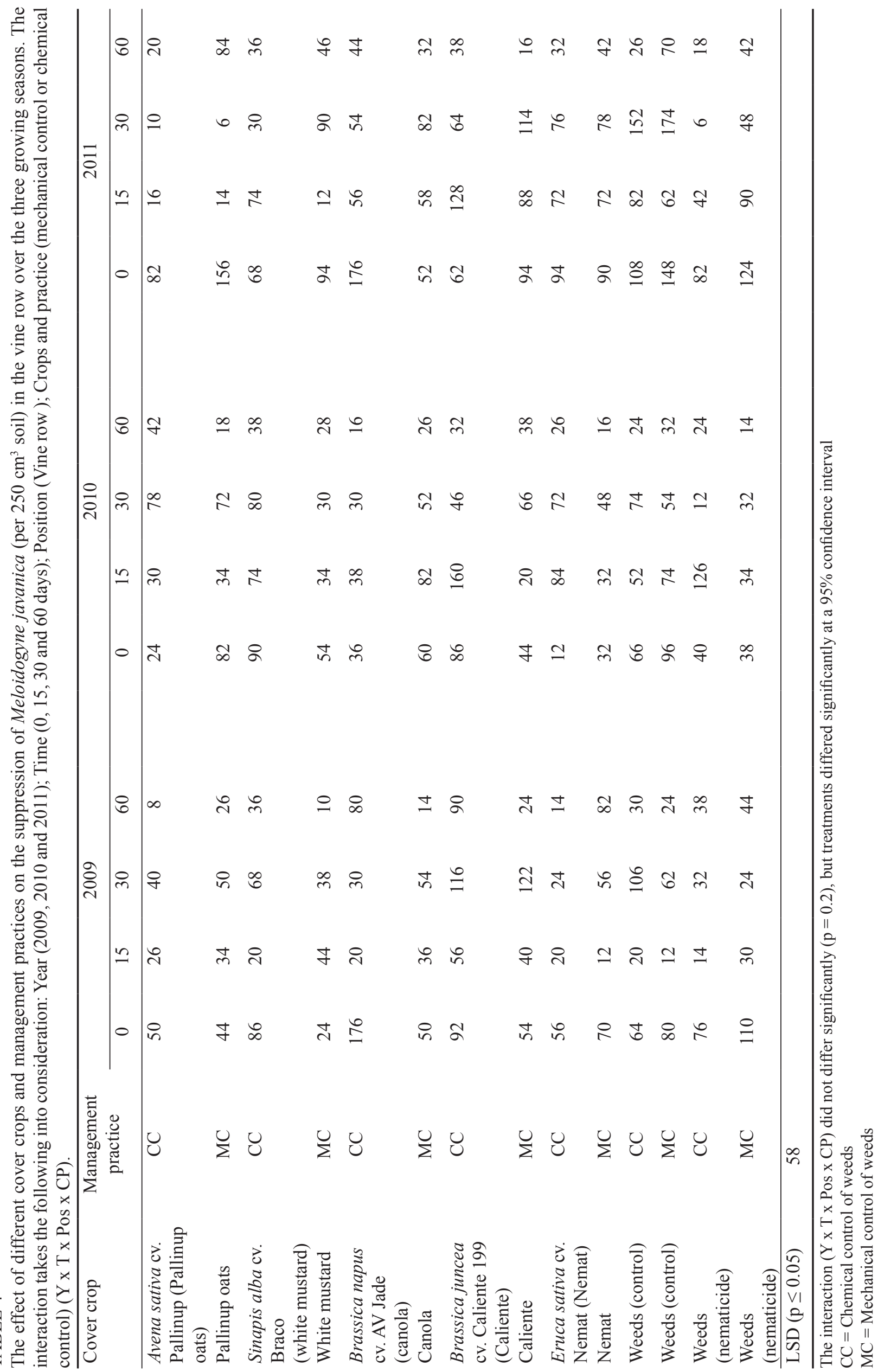




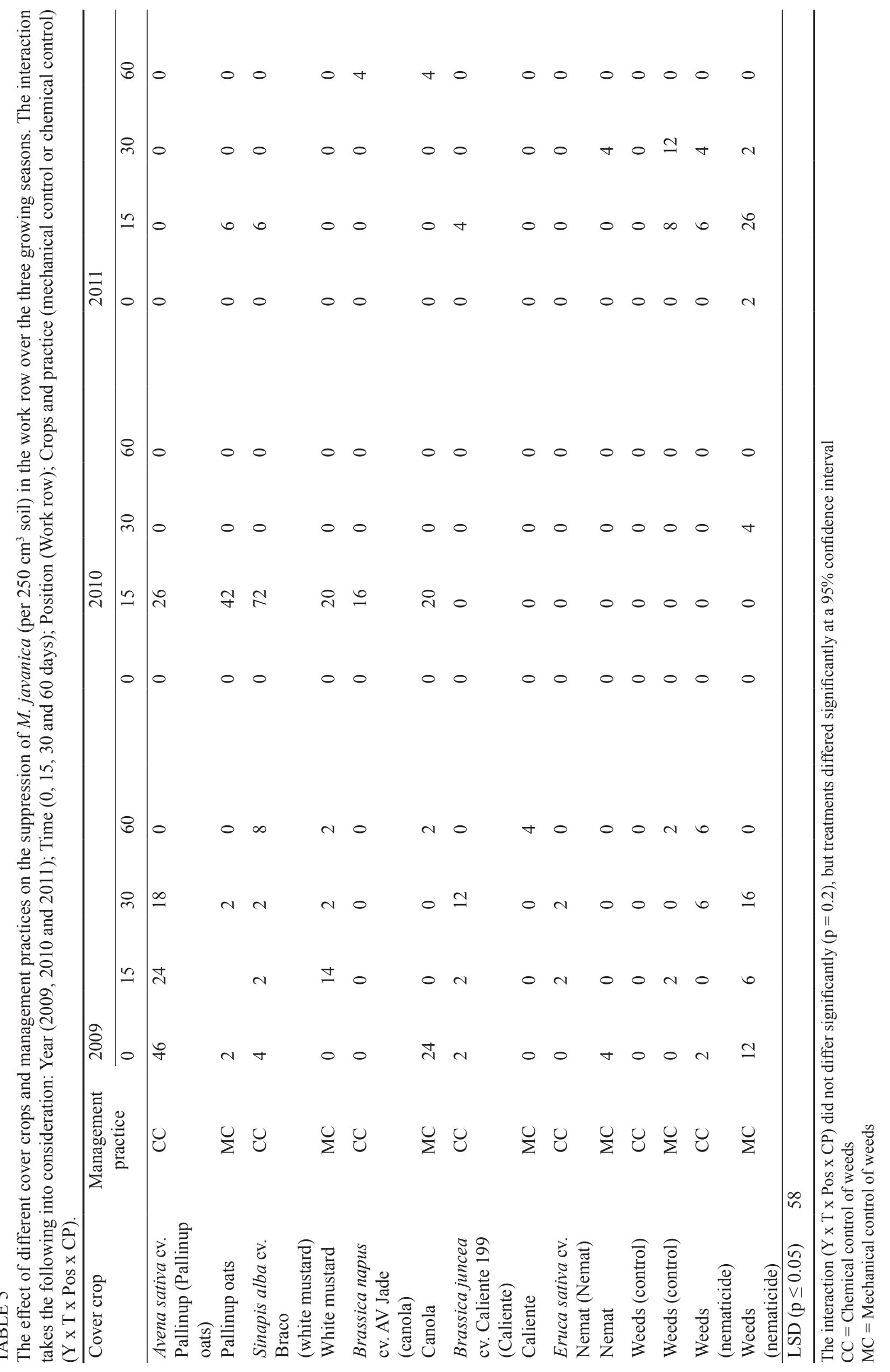


numbers in the vine row did not show any significant trend, except for the 15 days after the management practice period (Fig. 7). Significantly less $M$. javanica was present in the vine row, where the $\mathrm{MC}$ was applied, compared to the $\mathrm{CC}$. The same trend is present as for the $C$. xenoplax when 0 days (CC and MC) and 60 days (CC and MC) are compared, with a significantly lower number of $M$. javanica present at 60 days.

\section{CONCLUSIONS}

The two cover crops, canola and Caliente, showed the best potential for the suppression of $C$. xenoplax. For the biofumigation reaction to be optimal, a wide range of conditions should be met, including biomass production, soil moisture, the physiological stage of the crop, the maceration process, the GSL concentration, the specific ITC released during the biofumigation process and the incorporation process. In this field trial, none of the above-mentioned

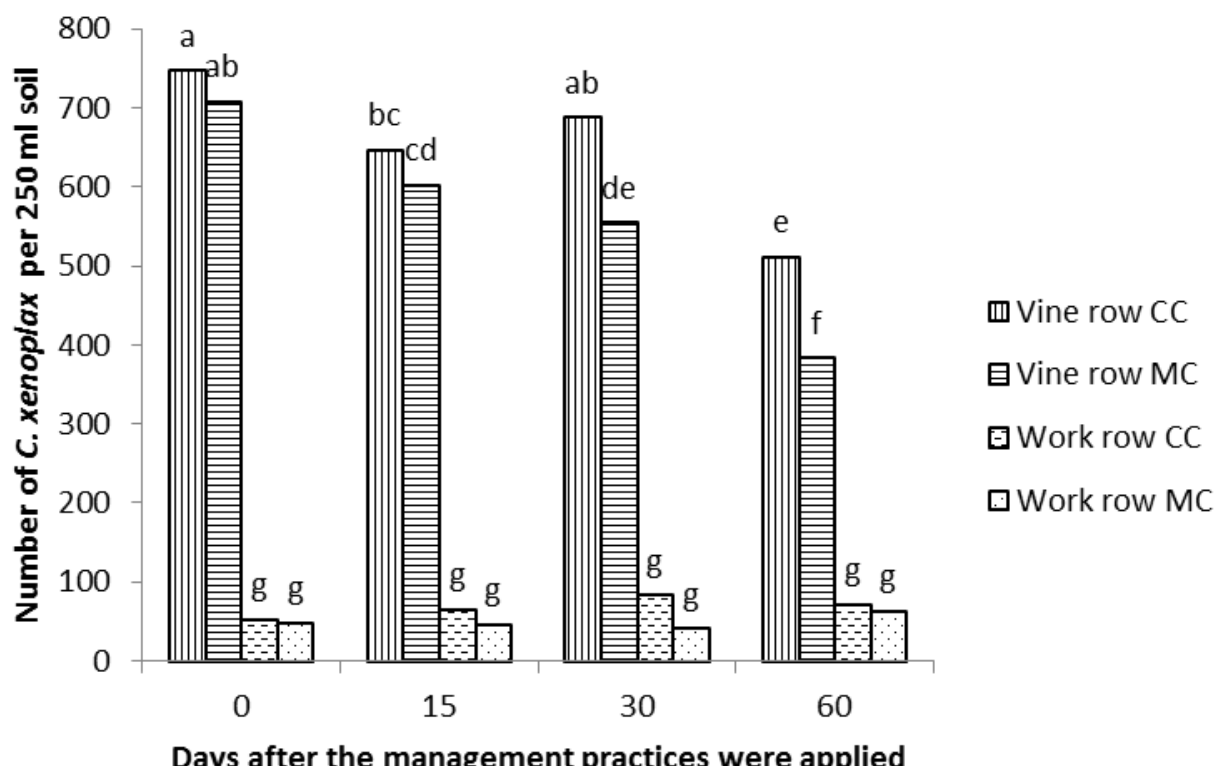

FIGURE 6

The effect of both chemical control (CC) and mechanical control (MC) on the Criconemoides xenoplax numbers in the vine and work row at day 0 , day 15 , day 30 and day 60 . The data for the three years was combined (Interaction Time $\mathrm{x}$ Position $\mathrm{x}$

Practice). T-test (95\% confidence interval) $\mathrm{LSD}=12.73$.

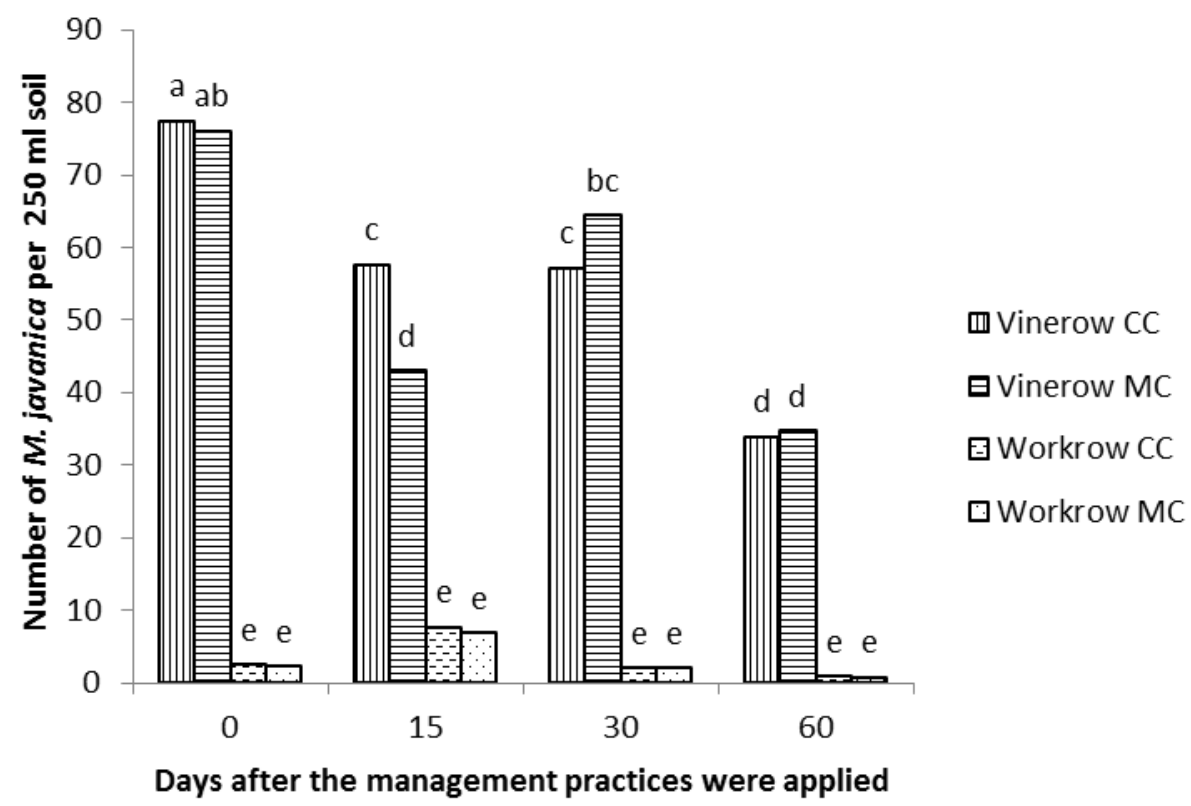

FIGURE 7

The effect of both chemical control (CC) and mechanical control (MC) on the Meloidogyne javanica numbers in the vine and work row at day 0 , day 15 , day 30 and day 60 . The data for the three years was combined (Interaction Time $\mathrm{x}$ Position $\mathrm{x}$

Practice). T-test $(95 \%$ confidence interval) $\mathrm{LSD}=12.73$. 
factors could be performed optimally due to the limitation in the irrigation system and the potential negative impact of excessive cover crop fertilisation on wine quality. However, the conditions under which the trials were conducted represent a large percentage of grape cultivation practices in South Africa and, even under the suboptimal conditions described for the biofumigation process, very promising results were obtained with regard to plant-parasitic nematode suppression.

It therefore is recommended that the cover crops concerned be implemented as part of an integrated approach to total plant-parasitic nematode suppression, with a specific focus on $C$. xenoplax management. The results obtained in this study can be ascribed mainly to the nematode host status of the two crops involved. The treatment would be more effective if the biofumigation concept could be developed further under more ideal field conditions and cultural practices. Future research is needed to allow for the refining of the biofumigation concept under field conditions, as it shows promise, as demonstrated in previous research, in relation to a range of nematodes, diseases and weeds where green manure crops were implemented.

The impact of the green manure on the structure and function of nematode soil communities, and indirectly on 'soil health', is another topic that would be of importance in understanding the impact of different cropping systems on the numbers of plant-parasitic and free-living nematodes in the soil.

\section{LITERATURE CITED}

Addison, P. \& Fourie, J.C., 2008. Cover crop management in vineyards of the Lower Orange River Region, South Africa: 2. Effect on plant parasitic nematodes. S. Afr. J. Enol. Vitic. 29, 26-32.

Brown, P.D. \& Morra, M.J., 1997. Control of soilborne plant pests using glucosinolate-containing plants. Adv. Agron. 61, 167-231.

Buckerfield, J.C. \& Webster, K.A., 1996. Earthworms, mulching, soil moisture and grape yields. Wine Indust. J. 11, 47-53.

Challenger, F., 1959. Aspects of the organic chemistry of sulphur. Butterworths, London.

Fahey, J.W., Zalcmann, A.T. \& Talalay, P., 2001. The chemical diversity and distribution of glucosinolates and isothiocyanates among plants. Phytochem. 56, 5-51.

Fenwick, G.R., Heaney, R.K. \& Mullin, W.J., 1983. Glucosinolates and their breakdown products in food and food plants. In: Furia, T.E. (ed). Critical reviews in food science and nutrition. CRC Press, Boca Raton. pp. $123-201$.

Ferris, H. \& McKenry, V., 1975. Relationship of grapevine yield and growth to nematode densities. J. Nematol. 7, 295-304.

Fourie, J.C., 2010. Soil management in the Breede River Valley wine grape region, South Africa. 1. Cover crop performance and weed control. S. Afr. J. Enol. Vitic. 31, 14-21.

Fourie, J.C. \& Freitag, K., 2010. Soil management in the Breede River Valley Wine Grape Region, South Africa. 2. Soil temperature. S. Afr. J. Enol. Vitic. 31, 165-168.

Fourie, J.C, Kruger, D.H.M. \& Malan, A.P., 2015. Effect of management practices applied to cover crops with bio-fumigation properties on cover crop performance and weed control in a vineyard. S. Afr. J. Enol. Vitic. 36, 146-153.
Fourie, J.C., Louw, P.J.E. \& Agenbag, G.A., 2005. Cover crop management in a Sauvignon blanc/Ramsey vineyard in the semi-arid Olifants River Valley, South Africa. 1. Effect of management practices on selected grass and broadleaf species. S. Afr. J. Enol. Vitic. 26, 131-139.

Fourie, J.C., Louw, P.J.E. \& Agenbag, G.A., 2006. Cover crop management in a Chardonnay/99 Richter vineyard in the Coastal wine grape region, South Africa. 1. Effect of two management practices on selected grasses and broadleaf species. S. Afr. J. Enol. Vitic. 27, 167-177.

Hugo, H.J., Mouton, C. \& Malan, A.P., 2014. Accelerated microbial degradation of nematicides in vineyard and orchard soils. S. Afr. J. Enol. Vitic. 35, 157-166.

Jenkins, W.R., 1964. A rapid centrifugal-flotation technique for separating nematodes from soil. Pl. Dis. Rep. 48, 692.

Kirkegaard, J.A., Wong, P.T.W. \& Desmarchelier, J.M., 1996a. In vitro suppression of fungal root pathogens of cereals by Brassica tissue. Plant Pathol. 45, 593-603.

Kirkegaard, J.A., Wong, P.T.W., Desmarchelier, J.M. \& Sarwar, N., 1996b. Suppression of soilborne cereal pathogens and inhibition of wheat germination by mustard seed meal. In: Proc. $8^{\text {th }}$ Austr. Agron. Conf., Toowoomba. pp. $353-356$.

Kleynhans, K.P.N., Van den Berg, E., Swart, A., Marais, M. \& Bucley, N.H., 1996. Plant nematodes in South Africa. Handbook no 8, Plant Protection Research Institute, Pretoria, South Africa.

Kruger, D.H.M., Fourie, J.C. \& Malan, A.P., 2015. Control potential of Brassicaceae cover crops as green manure and their host status for Meloidogyne javanica and Criconemoides xenoplax. S. Afr. J. Enol. Vitic. $36,165-174$.

Larkin, R.P. \& Griffin, T.S., 2007. Control of soilborne potato diseases using Brassica green manures. Crop Protec. 26, 1067-1077.

Larkin, R.P. \& Honeycutt, C.W., 2006. Effects of different 3-yr cropping systems and soil microbial communities and soilborne disease of potato. Phytopathol. 96, 68-79.

Lazzeri, L., Curto, G., Leoni, O. \& Dallavale, E., 2004a. Effects of glucosinolates and their enzymatic hydrolysis products via myrosinase on the root-knot nematode Meloidogyne incognita (Kofoid et White) Chitw. J. Agric. Food Chem. 52, 6703-6707.

Lazzeri, L., Leoni, O. \& Manici, L.M., 2004b. Biocidal plant dried pellets for biofumiogation. Ind. Crop Prod. 20, 59-65.

Lazzeri, L., Tacconi, R. \& Palmieri, S., 1993. In vitro activity of some glucosinolates and their reaction products toward a population of nematode Heterodera schachtii. J. Agric. Food Chem. 41, 825-829.

Loubser, J.T. \& Meyer, A.J., 1987a. Population dynamics of the root-knot nematodes Meloidogyne incognita Chitwood and Meloidogyne javanica Chitwood on grapevines in two different regions of South Africa. S. Afr. J. Enol. Vitic. 8, 36-40.

Loubser, J.T. \& Meyer, A.J., 1987b. Resistance of grapevine rootstocks to Meloidogyne incognita under field conditions. S. Afr. J. Enol. Vitic. 8, 7074.

Louw, P.J.E. \& Bennie, A.T.P., 1992. Water runoff and soil erosion in vineyard soils. Aust. Grapegrow. Winemak. Ann. Tech. Issue, 100-113.

Malan, A.P. \& Meyer, A.J., 1992. Transmission of grapevine fanleaf virus by South African populations of Xiphinema index. Phytophylactica 24, 217 219.

Malan, A.P. \& Meyer, A.J., 1994. Distribution of Longidoridae in the viticultural regions of the Cape Province. S. Afr. J. Enol. Vitic. 15, 12-16.

Malan, A.P. \& Meyer, A.J., 1999. The reproduction and life cycle of a South African population of Xiphinema index. S. Afr. J. Enol. Vitic. 20, 57-60. 
Matthiessen, J.N., Warton, B. \& Schackleton, M.A., 2004. The importance of plant maceration and water addition in achieving high Brassica-derived isothiocyanate levels in soil. Agroindustria 3, 277-280.

McKenry, M.V., 1992. Nematodes. In: Flaherty, D.L., Christensen, L.P., Lenin, W.T., Marois, J.J., Phillips, P.A. \& Wilson, L.T. (eds.). Grape pest management ( $2^{\text {nd }}$ ed). Publication no. 3343, Division of Agricultural Science, University of California, Berkeley, CA. pp. 279 - 293.

McLeod, R.W. \& Steel, C.C., 1999. Effects of brassica-leaf green manures and crops on the activity and reproduction of Meloidogyne javanica. Nematol. 1, 613-624.

Melakeberhan, H., Xu, A., Kravchenko, A., Mennan, S. \& Riga, E., 2006 Potential use of aragula (Eruca sativa L.) as a trap crop for Meloidogyne hapla. Nematol. 8, 793-799.

Mojtahedi, H., Santo, G.S., Hang, A.N. \& Wilson, J.H., 1991. Suppression of root-knot nematode populations with selected rapeseed cultivars as green manure. J. Nematol. 23, 170-174.

Mojtahedi, H., Santo, G.S., Wilson, J.H. \& Hang, A.N., 1993. Managing Meloidogyne chitwoodi on potato with rapeseed as green manure. Pl. Dis. 77, 42-46.

Monfort, W.S., Csinos, A.S., Desaeger, J., Seebold, K., Webster, T.M \& Diaz-Perez, J.C., 2007. Evaluating brassica species as an alternative control measure of root-knot nematode ( $M$. incognita) in Georgia vegetable plasticulture. Crop Protec. J. 26,1359-1368.

Morra, M.J. \& Kirkegaard, J.A., 2002. Isothiocyanate release from soilincorporated Brassica tissues. Soil Biol. Biochem. 34, 1683-1690.

Myburgh, P.A., 1998. Water consumption in South African vineyards: A modeling approach based on the quantified combined effects of selected viticultural, soil and meteorological parameters. $\mathrm{PhD}$ dissertation, Stellenbosch University, Private Bag X1, 7602 Matieland (Stellenbosch), South Africa.

Nicol, J.M., Stirling, J.R., Rose, B.J., May, P. \& Van Heeswijck, R., 1999. Impact of nematodes on grapevine growth and productivity: Current knowledge and future directions, with special reference to Australian viticulture. Aus. J. Grape Wine Res. 5, 109-127.

Pinkerton, J.N., Forge, T.A., Ivors, K.L. \& Ingham, R.E., 1999. Plantparasitic nematodes associated with grapevines Vitis vinifera, in Oregon vineyards. J. Nematol. 31, 624-634.
Poulton, J.E. \& Moller, B.L., 1993. Glucosinolates. In: Leah, P.J. (ed.). Methods in plant biochemistry, vol. 9. PJ Academic Press, London. pp. 209 -237 .

Rahman, L. \& Somers, T., 2005. Suppression of root knot nematode (Meloidogyne javanica) after incorporation of Indian mustard cv. Nemfix as green manure and seed meal in vineyards. Aust. P1. Path. 34, 77-83.

Sarwar, M., Kirkegaard, J.A., Wong, P.T.W. \& Desmarchelier, J.M., 1998. Biofumigation potential of brassicas. III. In vitro toxicity of isothiocyanates to soil-borne fungal pathogens. Plant \& Soil 201, 103-112.

SAS, 1990. SAS/STAT users guide, version 8, first edition, volume 2. SAS Institute Inc., Campus Drive, Cary NC 27513.

Seinhorst, J.W. \& Sauer, M.R., 1956. Eelworm attacks on vines in the Murray Valley irrigation area. J. Austr. Inst. Agric. Sci. 22, 296-299.

Shapiro, S.S. \& Wilk, M.B., 1965. An analysis of variance test for normality (complete samples). Biometrika 52, 591-611.

Smith, P.C., 1977. Distribution of plant-parasitic nematodes in vineyards in the Western Cape province. Phytophylactica 9, 27-28.

Stirling, G., \& Potter, M., 1998. Brassicas may play a role in biofumigation. Good Fruit and Vegetables 9, 48-49.

Stirling, G.R., 2014. Biological control of plant-parasitic nematodes. CABI, Wallingford, UK.

Stirling, G.R. \& Stirling, A.M., 2003. The potential of Brassica green manure crops for controlling root-knot nematode (Meloidogyne javanica) on horticultural crops in a subtropical environment. Aust. J. Exp. Agric. 43, 623-630.

Storey, S., 2012. Understanding ring nematode. Available at: www.nemlab. co.za

Van Huyssteen, L., Van Zyl, J.L. \& Koen, A.P., 1984. The effect of cover crop management on soil conditions and weed control in a Colombar Vineyard in Oudtshoorn. S. Afr. J. Enol. Vitic. 5, 7-17.

Walker, G.E. \& Stirling, G.R., 2008. Plant-parasitic nematodes in Australian viticulture: Key pests, current management practices and opportunities for future improvements. Aust. P1. Pathol. 37, 268-278. 